\title{
An Analysis on Bank Credit and Industrial Structure Upgrading of Beijing-Tianjin-Hebei Region-Based on Technological Innovation Mode
}

\author{
Qinglu Yuan ${ }^{1}$ and Huan Zhou ${ }^{2}$
}

\begin{abstract}
Facing different technological innovation mode, there is a significant difference in the industrial structure effect of bank credit, this would have important research significance for technological innovation mode selection in Beijing-Tianjin-Hebei Region. Based on the data of 43 cities in the Beijing-Tianjin-Hebei region for the period of 2009-2016, this paper builds a panel threshold model to analysis the industrial structure effect of bank credit. The result shows that: bank credit has a nonlinear industrial structure effect in the Beijing-Tianjin-Hebei region under the current level of economic development. The impetus for indigenous innovation plays a sustained and significant boosting role in it, and it promote to resources translocation from secondary industry to tertiary industry. However, the technology import is gradually lost, even becomes negative effect. The policy suggestion is: firstly, the Beijing-Tianjin-Hebei region needs to increase introduction of high quality technology, in order to raise the level of technological innovation. Secondly, the Beijing-Tianjin-Hebei region needs to adhere to the development strategy of indigenous innovation, in order to promote the upgrading of the industrial structure.
\end{abstract}

Keywords: Bank Credit, Beijing-Tianjin-Hebei Region, Industrial Structure Upgrading, Technological Innovation, Threshold Model.

\footnotetext{
${ }^{1}$ Institute of Disaster of Prevention, Beijing 101601, P.R. China.

${ }^{2}$ Business School, University of Shanghai for Science and Technology, Shanghai 200093, P.R. China.
} 


\section{Introduction}

Socialism with Chinese characteristics has entered a new era, and China's economy has been transitioning from a phase of rapid growth to a stage of high-quality development. In developing a modernized economy, the driving force of China's economic growth has gradually shifted from factor-driven and investment-driven to innovation-driven(Zhou et al., 2020). The 19th National Congress of the Communist Party of China (CPC) pointed out that it was imperative to implement the strategy of innovation-driven development. Scientific and technological innovation must be placed at the core of the overall national development, and the path of indigenous innovation with Chinese characteristics must be adhered to. Meanwhile, China will promote the strategic adjustment of economic structure and accelerate the optimization and upgrading of traditional industries. In order to make scientific and technological innovation an engine driving industrial structure continuously, it is necessary to provide long-term and stable credit fund support for scientific and technological innovation(Li \& Zhou, 2018). Bank credit can not only provide financial support for technological innovation, but also promote technological innovation from various aspects such as risk management, regulatory mechanism, information processing, cultivation of innovation spirit, improvement of self-innovation ability and improvement of production efficiency (Rajan \& Zingales, 1998).

There are two main types of technological innovation. One is to rely on the indigenous innovation of domestic enterprises or R\&D institutions. The other is to use technology import to acquire technology from other countries, and to imitate, process and re-create them. Lin \& Zhang (2005) pointed out that the purpose of innovation was to use more efficient technology than the current period. But there is no consensus on the choice of technological innovation models either in theory or in practice(Raustiala \& Sprigman, 2012; Xue, 2013; Fang \& Xing, 2017). Developed countries are at the forefront of world technology and can only rely on indigenous innovation to obtain production efficiency improvements. However, for developing countries, there is a big gap between production efficiency and developed countries. Importing foreign mature technologies is also an important part of technological innovation. Since the reform and opening up 40 years ago, China's economic development has taken the development road of focusing on technology import and supplemented by indigenous innovation. With the development of social economy, Chinese enterprises have been improving their awareness of indigenous innovation. The proportion of $R \& D$ investment and $R \& D$ personnel is also increasing, but there is still a big gap with foreign countries in terms of core technology. Then, does China currently have the ability to choose indigenous innovation to achieve technological catch-up, or to adjust to a development strategy based on indigenous innovation and technology import?

The Beijing-Tianjin-Hebei region, as a metropolis with Beijing as its core, is a new engine for innovation-driven economic growth. At present, Beijing-Tianjin-Hebei faces many opportunities and challenges. In April 2015, the "Beijing-Tianjin-Hebei 
Collaborative Development Plan" required "to optimize and upgrade the industrial structure and achieve innovation-driven development as the focus of cooperation". In June 2016, the "Beijing-Tianjin-Hebei Industry Transfer Guide" further required "the development pattern of rational spatial layout, organic linkage of industrial chains, and optimal allocation of various production factors". However, the heterogeneity of the credit structure in the Beijing-Tianjin-Hebei region is very obvious, and the economic performance of the Beijing-Tianjin-Hebei region is unbalanced. What is urgently needed to be clear is that, with the improvement of the level of technological innovation, what are the characteristics of the impact of Beijing-Tianjin-Hebei bank credit on the industrial structure? Can we effectively combine technological innovation and bank credit to achieve the goal of industrial restructuring and upgrading? This paper will study the role of different technological innovation models in the Beijing-Tianjin-Hebei region in the structural effects of bank credit.

\section{Literature review}

This paper reviews the existing literature from the following three aspects.

1. The structural effect of bank credit. There are two views on the study of such problems. Some scholars believe that financial markets support the development of high-tech industries and high-risk industries, while banking structures can promote the development of traditional mature industries. If it is a bank-oriented financial system, the effect of promoting industrial restructuring and upgrading is not obvious(Mayer and Vives, 1993; Beck and Levine, 2002). Binh et al., (2005), Gong et al., (2014), Zhao \& Li, (2010); Duan and Song (2013) showed that bank credit had not promoted the optimization of industrial structure in general. Huang (2010) believed that credit withdrawal was the direct driving force to promote the transformation of industrial structure. Other scholars' research results showed that there was a significant correlation between bank credit and industrial structure (Angelos et al., 2011). Guo et al. (2009) showed that the expansion of bank credit scale supported the development of China's primary industry and secondary industry, but the impact on the tertiary industry was not significant.

2. The structural effect of technological innovation. Schumpeter (1912) conducted a thorough analysis of innovation and highlighted the interrelationship between innovation and industrial evolution. Pavitt (1984) constructed an industry-dependent model based on technological innovation and found that there are differences in technological innovation practices between different industries. Gereffi (1999), Ngai \& Pissarides (2007) found that enterprises accelerated the realization of technological innovation, which played a key role in the upgrading of industrial structure. Peneder (2003) found that technological innovation would influence the industrial structure by affecting 
the elasticity of demand income. Duarte \& Restuccia (2009) believed that technical progress would improve the efficiency of labor and capital, and would facilitate the re-allocation of social resources among industries, and would form industrial upgrading and industrial structure upgrading. Saviotti \& Pyka (2008) and Sengupta (2014) pointed out that technological innovation had created new products and gradually spawned new industrial sectors, and the original industrial structure had been transformed and upgraded. Some Chinese researchers have explored the impact of innovation on industrial upgrading from the perspective of innovation intensity. Xu \& Feng (2010) considered that the main obstacle to the upgrading of industrial structure in underdeveloped regions was the lack of technological innovation. Under certain space-time conditions, technological innovation or indigenous innovation was the direct driving force for the transformation and upgrading of China's industrial structure(Huang \& $\mathrm{Li}$, 2009; Gong et al., 2013).

3. Bank credit, technological innovation and industrial structure. A few scholars analyzed the relationship among bank credit, technological innovation and industrial structure. An empirical analysis by Amore et al. (2013) showed that the increase in the scale of bank credit would stimulate the innovation behavior of enterprises and promote industrial upgrading. Ding et al. (2014) and Lian et al. (2015) found that technological innovation incentives could guide the allocation of credit resources to high $\mathrm{R} \& \mathrm{D}$ investment enterprises, thus promoting the optimization and upgrading of industrial structure.

The above literature demonstrates the relationship among bank credit, technological innovation and industrial structure theoretically and empirically, but there are still parts of expansion and deepening. First, most studies have discussed the scale of bank credit and less on regional credit structure. Second, the existing studies mostly focus on a single relationship between technological innovation or bank credit and industrial structure, and lack of research on the relationship among technological innovation, bank credit and industrial structure. Neither the difference between indigenous innovation and technology import nor the interaction effect of indigenous innovation and technology import are taken into account. Third, less attentions have been paid to the non-linear effects of technology introduction and indigenous innovation and their interaction on the structural effects of bank credit. This paper will construct a panel threshold model and conduct an exploratory study on the industrial structure benefits of bank credit in the Beijing-Tianjin-Hebei region under different technological innovation modes. 


\section{Data and variables}

\subsection{Data sources}

This paper collects the economic data of 43 administrative prefecture-level cities in Beijing, Tianjin and Hebei province from 2009 to 2016, including 16 regions in Beijing, 16 regions in Tianjin, and 11 regions in Hebei Province. The added value of production in the industry, the bank credit balance, patent granted, the actual utilized foreign capital, total investment in fixed asset, the total number of employed persons of corporate units, and general public budget expenditures of the prefecturelevel cities of the provinces (cities) are mainly taken from the Beijing Regional Statistical Yearbook and the Tianjin Statistical Yearbook, and the Hebei Economic Yearbook. Part of the bank credit balance comes from the Regional Financial Yearbooks. Part of the supplementary data comes from statistical yearbooks and statistical bulletins from various cities. The number of patent granted in some prefecture-level cities in Tianjin is taken from the Tianjin Science and Technology Statistical Yearbook. The loan data of prefecture-level cities in Tianjin from 2009 to 2012 is supplemented by the China County (City) Social and Economic Statistics Yearbook. Most of the data collection is manually extracted and supplemented and verified by the commercial database. The data of the difference is subject to the announcement of the statistical department. Due to the merger of administrative divisions, Beijing Dongcheng District, Xicheng District and Tianjin Binhai New Area have different data calibers before and after the merger, and they are treated in a corresponding manner.

\subsection{Variables description}

This paper constructs the panel threshold model and analyzes the non-linear effects of Beijing-Tianjin-Hebei bank credit on industrial structure from different perspectives of indigenous innovation and technology import. The dependent variable is the industrial structure ratio, the key independent variable is the regional credit ratio of the relative indicator, and the threshold variable is the technological innovation, which mainly refers to the two modes of technology import and indigenous innovation. Other control variables include the ratio of investment in fixed asset, the ratio of employed persons, and government intervention. Most of the independent variables use the ratio indicator.

1. The ratio of industrial structure. The ratio of industrial structure(TSR) is the added value of production in the tertiary industry relative to that in the secondary industry. TSR is greater than 1, indicating that the industrial economic structure is increasingly advanced.

2. The ratio of regional credit. The ratio of regional credit $(L L D)$ is the bank credit balance relative to GDP. Where the bank credit balance refers to the RMB loan balance of Chinese Banks.

3. The ratio of indigenous innovation. The amount of patent granted represents the main actual output of enterprises' innovation activities and is used as the main index to evaluate enterprises' innovation ability. The ratio of indigenous 
innovation is expressed by the proportion of the number of patents granted. $P G R$ is the amount of patent granted in a certain region to the total amount of patent granted in the Beijing-Tianjin-Hebei region.

4. The ratio of technology import $(T Y D)$. The ratio of technology import is the actual foreign capital utilized in a region relative to the GDP of the region. Where the actual utilized foreign capital expressed in USD 10 million will be converted into RMB 100 million using the RMB exchange rate of that year.

5. The ratio of investment in fixed asset $(F A I R)$. FAIR is total investment in fixed asset in a region relative to total investment in fixed asset in Beijing-TianjinHebei region.

6. The ratio of employed persons $(C E R)$. CER is the ratio of the total number of employed persons of corporate units in a region to the total number of employed persons of corporate units in the Beijing-Tianjin-Hebei region.

7. Government intervention. Government intervention, also known as government spending rate, reflects the degree of government intervention in the economy. GID is the ratio of general public budget expenditures to GDP.

Table 1 shows the statistical description of key variables used in this paper.

Table 1: Statistical description of key variables (unit: \%).

\begin{tabular}{|c|c|c|c|c|}
\hline Variables & Mean & Std.Dev. & Min & Max \\
\hline TSR & 3.54 & 6.61 & 0.25 & 69.00 \\
\hline LLD & 1.23 & 1.13 & 0 & 6.74 \\
\hline PGR & 2.33 & 3.75 & 0.04 & 28.93 \\
\hline TYD & 0.03 & 0.03 & 0 & 0.20 \\
\hline FAIR & 2.36 & 2.78 & 0.15 & 14.50 \\
\hline CER & 2.33 & 2.31 & 0.15 & 12.98 \\
\hline GID & 0.19 & 0.15 & 0.02 & 0.89 \\
\hline
\end{tabular}




\section{Model estimation and result analysis}

The ratio of industrial structure is the explained variable, the ratio of regional credit is the core explaining variable, and indigenous innovation and technology import are threshold variables. The panel threshold model of industrial structure TSR is established (Hansen, 1999).

$$
T S R_{i t}=\alpha_{1} L L D_{i t} \bullet I\left(T I_{i t} \leq \gamma\right)+\alpha_{2} L L D_{i t} \bullet I\left(T I_{i t}>\gamma\right)+\Theta^{\prime} X_{i t}+\varepsilon_{i t}
$$

where TSR is the ratio of industrial structure, and $L L D$ is the ratio of regional credit. $T I$ represents the threshold variable, which is $P G R$ and TYD respectively. $X_{i t}$ represents the controlled variable, including FAIR, CER, GID, and TPR, where TPR is the interaction of $P G R$ and $T Y D$, and the time control variable is added. $\alpha_{i}$ are parameters to be estimated, $\gamma$ represents the threshold quantity. The indicative function $I(\bullet)$ is then constructed. $\varepsilon_{i t}$ represents the residual term, and $\varepsilon_{i t} \sim$ i.i.dN $\left(0, \sigma^{2}\right)$.

Since the credit supply and the industrial structure are mutually influential, in order to avoid the influence of endogenousity, the lag value of the regional credit is used as a tool variable. Based on model (1), the threshold value and its $95 \%$ asymptotic confidence interval are estimated. The results are shown in Table 3.

Table 3: Threshold value estimation and confidence interval

\begin{tabular}{|c|c|c|c|c|}
\hline $\begin{array}{c}\text { Threshold } \\
\text { value }\end{array}$ & $\begin{array}{c}\text { Threshold } \\
\text { estimation } \\
\text { value }\end{array}$ & $\begin{array}{c}\text { 95\% asymptotic } \\
\text { confidence } \\
\text { interval }\end{array}$ & $\begin{array}{c}\text { Threshold } \\
\text { estimation } \\
\text { value }\end{array}$ & $\begin{array}{c}\text { 95\% asymptotic } \\
\text { confidence } \\
\text { interval }\end{array}$ \\
\hline $\begin{array}{c}\text { Single } \\
\text { threshold } \\
\text { model }\end{array}$ & $0.230 \%$ & $\begin{array}{c}{[0.230 \%,} \\
0.250 \%]\end{array}$ & 0.047 & {$[0.045,0.052]$} \\
\hline \multicolumn{4}{|c|}{ Double threshold model } & {$[0.059,0.059]$} \\
\hline $\begin{array}{c}\text { First } \\
\text { threshold }\end{array}$ & $0.780 \%$ & $\begin{array}{c}{[0.780 \%,} \\
0.810 \%]\end{array}$ & 0.059 & {$[0.047,0.047]$} \\
\hline $\begin{array}{c}\text { Second } \\
\text { threshold }\end{array}$ & $0.230 \%$ & $\begin{array}{c}{[0.230 \%,} \\
0.250 \%]\end{array}$ & 0.047 & \\
\hline
\end{tabular}

In this paper, Bootstrap method was adopted to set the estimation model (1) with 0 threshold, 1 threshold and 2 thresholds successively. As can be seen from table 4 and table 5, both the single threshold model and the double threshold model have significant $\mathrm{F}$ values. For the sake of simplification, the double threshold regression model (2) and model (3) are selected for analysis. 


$$
\begin{aligned}
& T S R_{i t}=\alpha_{1} L L D_{i t} \bullet I\left(P G R_{i t} \leq \gamma_{1}\right)+\alpha_{2} L L D_{i t} \bullet I\left(\gamma_{1}<P G R_{i t} \leq \gamma_{2}\right)+\alpha_{3} L L D_{i t} \bullet I\left(P G R_{i t}>\gamma_{2}\right) \\
& +\alpha_{4} F A I R_{i t}+\alpha_{5} C E R_{i t}+\alpha_{6} G I D_{i t}+\alpha_{7} T P R_{i t}+\varepsilon_{i t} \\
& T S R_{i t}=\beta_{1} L L D_{i t} \bullet I\left(T Y D_{i t} \leq \eta_{1}\right)+\beta_{2} L L D_{i t} \bullet I\left(\eta_{1}<T Y D_{i t} \leq \eta_{2}\right)+\beta_{3} L L D_{i t} \bullet I\left(T Y D_{i t}>\eta_{2}\right) \\
& +\beta_{4} F A I R_{i t}+\beta_{5} C E R_{i t}+\beta_{6} G I D_{i t}+\beta_{7} T P R_{i t}+\varepsilon_{i t}
\end{aligned}
$$

Table 4: The significance test results for PGR threshold effects.

\begin{tabular}{|c|c|c|c|c|c|}
\hline \multirow{2}{*}{ Type } & \multirow{2}{*}{ F-value } & \multirow{2}{*}{ P-value } & \multicolumn{3}{|c|}{ Bootstrap threshold (500 times) } \\
\cline { 4 - 6 } & & $1 \%$ & $5 \%$ & $10 \%$ \\
\hline $\begin{array}{c}\text { Single } \\
\text { threshold }\end{array}$ & $81.805^{*}$ & 0.02 & 500 & 98.696 & 21.813 \\
\hline $\begin{array}{c}\text { Double } \\
\text { threshold }\end{array}$ & $55.756^{*}$ & 0.016 & 500 & 83.57 & 15.574 \\
\hline
\end{tabular}

Note: *denotes statistical significance levels at $5 \%$.

Table 5: The significance test results for TYD threshold effects.

\begin{tabular}{|c|c|c|c|c|c|}
\hline \multirow{2}{*}{ Type } & \multirow{2}{*}{ F-value } & \multirow{2}{*}{ P-value } & \multicolumn{3}{|c|}{ Bootstrap threshold(500 times) } \\
\cline { 4 - 6 } & & $1 \%$ & $5 \%$ & $10 \%$ \\
\hline $\begin{array}{c}\text { Single } \\
\text { threshold }\end{array}$ & $48.506^{*}$ & 0.036 & 94.855 & 17.171 & 4.871 \\
\hline $\begin{array}{c}\text { Double } \\
\text { threshold }\end{array}$ & $57.091^{*}$ & 0.016 & 70.514 & 13.095 & 4.297 \\
\hline
\end{tabular}

Further, the estimated threshold value is tested. According to Hansen (1999), the $95 \%$ confidence interval graph of the threshold estimation value can be constructed as shown in Figure 1 and Figure 2, respectively. The result can reflect the construction process of confidence interval and threshold value directly through likelihood ratio function graph. Figure 1a and Figure $2 \mathrm{a}$ are the $95 \%$ confidence intervals for the threshold values of the two single threshold models. The threshold values all fall in the interval below the dotted line of LR values, which proves that the threshold value is valid, and it can be seen that there may be a slightly larger threshold value. Figure $1 b$ and Figure $2 b$ are the first threshold values for the two double threshold models, respectively. And Figure 1c and Figure 2c are the two second threshold values, respectively. 


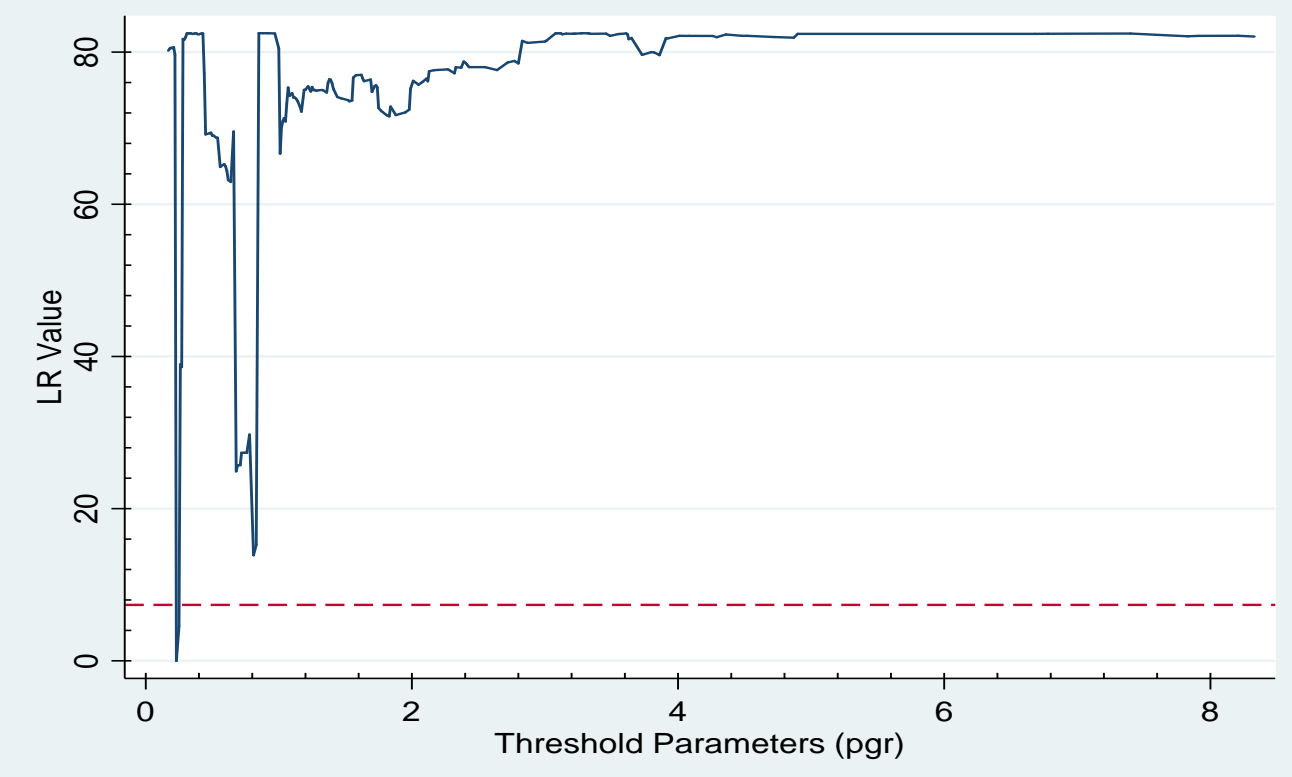

Figure 1: The LR function diagram of PGR

Figure 1a: The LR function diagram of the single threshold model

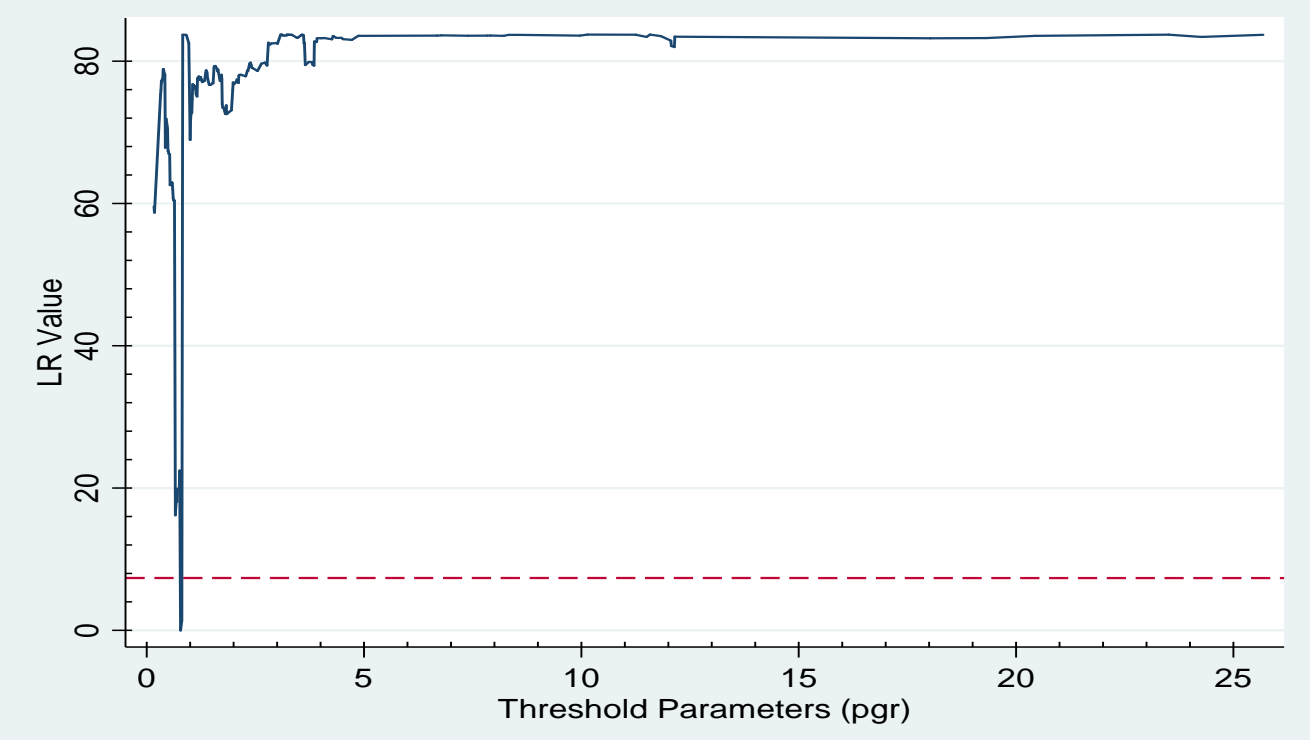

Figure 1b: The LR function diagram of the double threshold model 


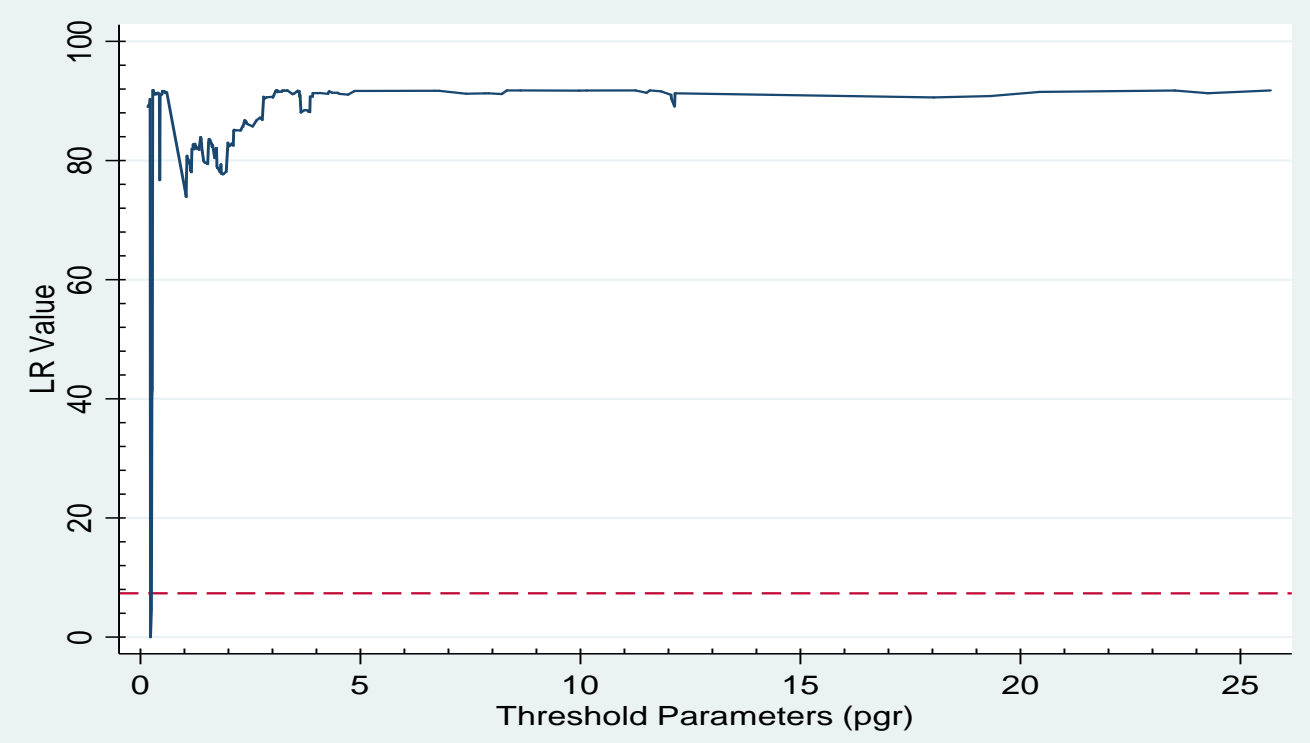

Figure 1c: The LR function diagram of the double threshold model 


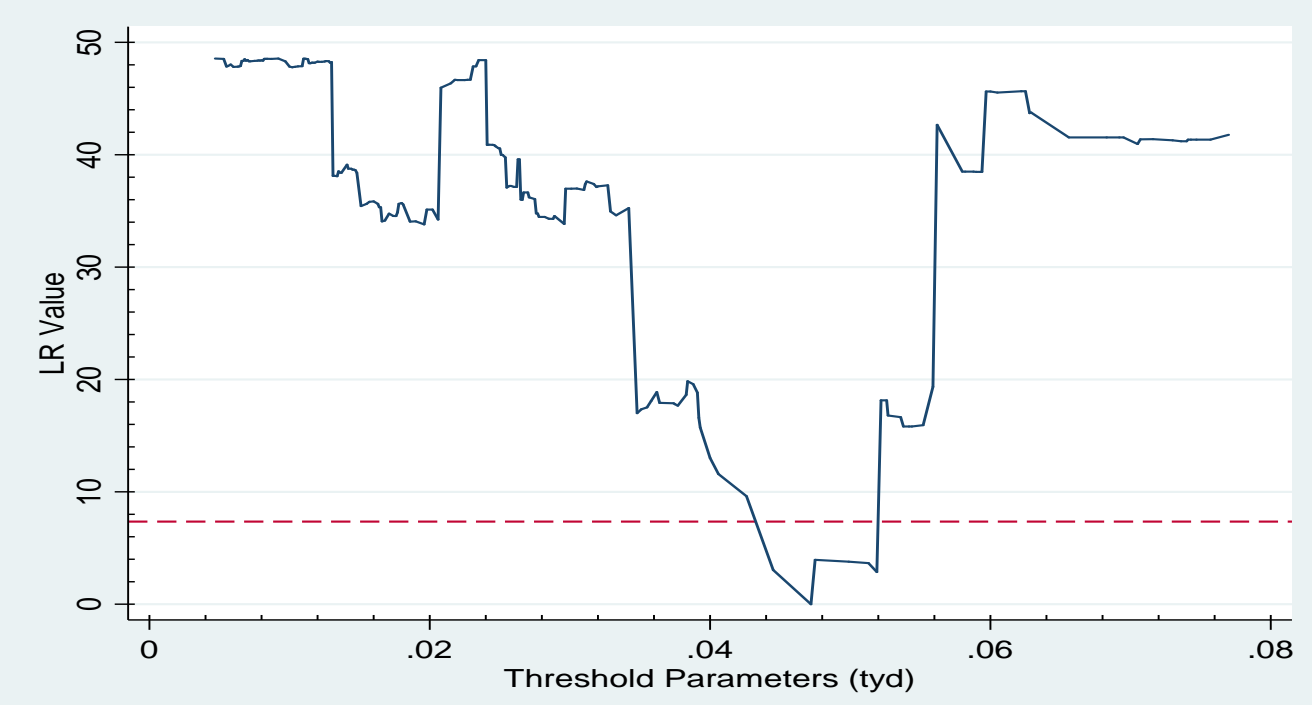

Figure 2: The LR function diagram of TYD

Figure 2a: The LR function diagram of the single threshold model

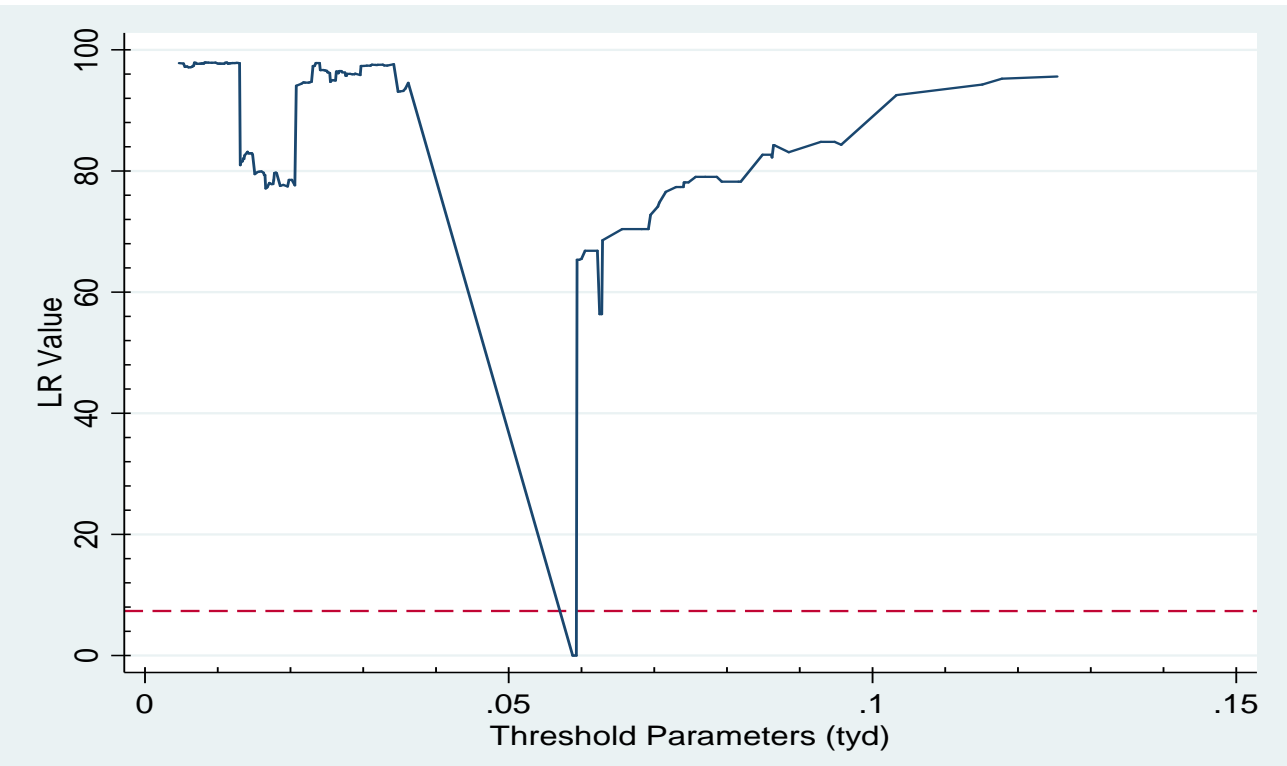

Figure 2b: The LR function diagram of the double threshold model 


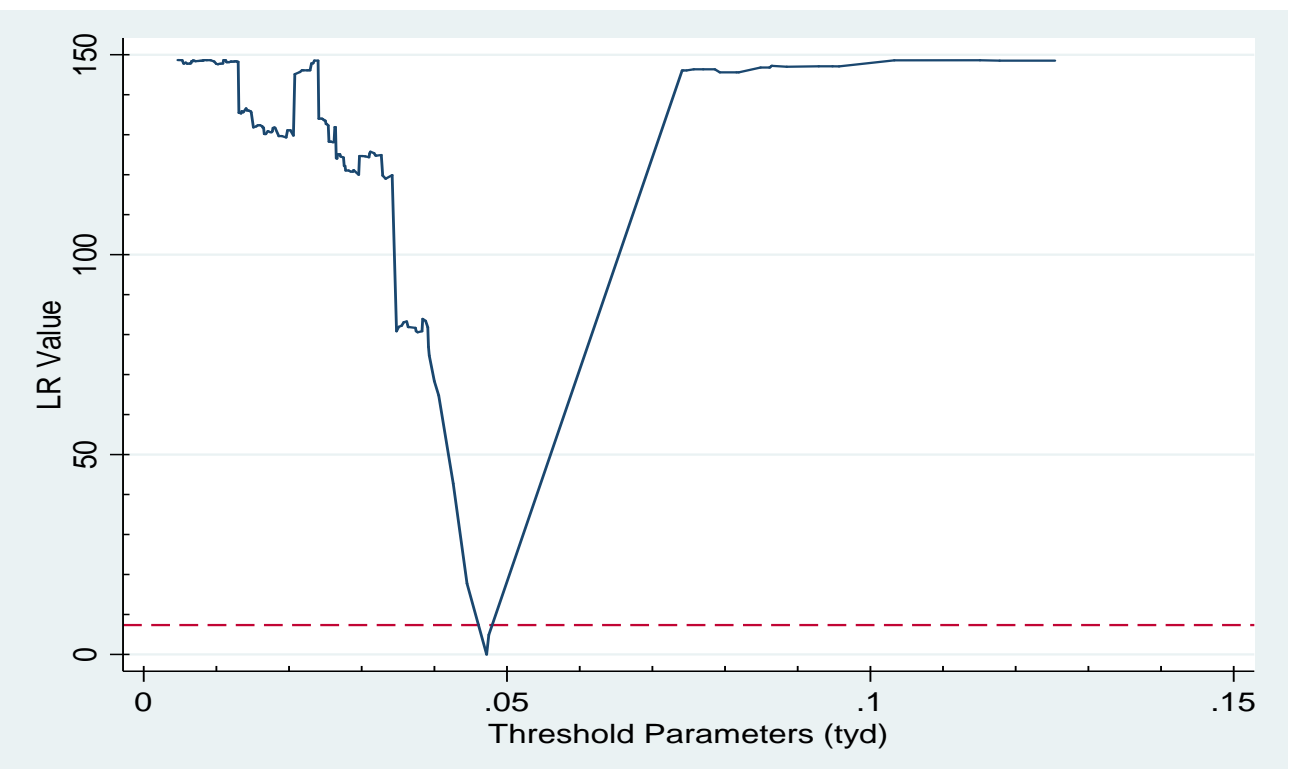

Figure 2c: The LR function diagram of the double threshold model

Threshold effect regression was performed for model (2) and model (3). Table 6 lists the regression results and compares the estimated results without interaction. There is a significant double threshold effect between regional credit and industrial structure upgrading. At the different thresholds of $P G R$, the effect of regional credit on industrial structure has changed significantly. This process of change is divided into three different zones, namely, low-level zone, medium-level zone, and highlevel zone. When $P G R$ is not higher than $0.78 \%$, that is, in the low-level zone and the medium-level zone, the impact of regional credit on the industrial structure is negative and not significant. When $P G R$ is higher than $0.78 \%$, that is, in the highlevel zone, and the influence of regional credit on the industrial structure is significantly between 1.895 and 1.904 . The results show that in the Beijing-TianjinHebei, where the ratio of indigenous innovation is low, the credit supply has no adjustment effect on the industrial structure. In regions with high ratio of indigenous innovation, the adjustment of industrial structure of credit supply has positive effect. The stronger the ability of indigenous innovation is, the more credit funds are focused on the tertiary industry, which leads to a significant increase in the industrial structure. This means that, in developing a modernized economy, the role of indigenous innovation in the effect of the industrial structure of credit gradually becomes stronger. 
Table 6: The test results of instrumental variables with a lag of one period.

\begin{tabular}{|c|c|c|c|c|}
\hline \multirow[t]{2}{*}{ Type } & \multicolumn{2}{|c|}{ PGR threshold } & \multicolumn{2}{|c|}{ TYD threshold } \\
\hline & $\begin{array}{c}\text { no interaction } \\
\text { item }\end{array}$ & $\begin{array}{c}\text { interaction } \\
\text { item }\end{array}$ & $\begin{array}{c}\text { no interaction } \\
\text { item }\end{array}$ & $\begin{array}{c}\text { interaction } \\
\text { item }\end{array}$ \\
\hline cons & $\begin{array}{c}3.330 * * \\
(3.34)\end{array}$ & $\begin{array}{c}3.892 * * \\
(3.61)\end{array}$ & $\begin{array}{c}2.341^{*} \\
(2.31)\end{array}$ & $\begin{array}{c}2.907 * * \\
(2.66)\end{array}$ \\
\hline FAIR & $\begin{array}{c}-0.556^{* *} \\
(-3.07)\end{array}$ & $\begin{array}{c}-0.624 * * \\
(-3.33)\end{array}$ & $\begin{array}{c}-0.449 * \\
(-2.45)\end{array}$ & $\begin{array}{c}-0.516^{* *} * \\
(-2.72)\end{array}$ \\
\hline CER & $\begin{array}{c}0.432 * * \\
(2.87)\end{array}$ & $\begin{array}{l}0.298 \\
(1.66)\end{array}$ & $\begin{array}{c}0.442 * * \\
(2.89)\end{array}$ & $\begin{array}{l}0.307 \\
(1.69)\end{array}$ \\
\hline GID & $\begin{array}{l}0.410 \\
(0.16)\end{array}$ & $\begin{array}{l}0.429 \\
(0.16)\end{array}$ & $\begin{array}{c}-0.0848 \\
(-0.03)\end{array}$ & $\begin{array}{l}-0.0749 \\
(-0.03)\end{array}$ \\
\hline TPR & l & $\begin{array}{l}-0.284 \\
(-1.37)\end{array}$ & $(10.00)$ & $\begin{array}{l}-0.288 \\
(-1.37)\end{array}$ \\
\hline LLD $\times$ PGR 1 & $\begin{array}{l}-0.326 \\
(-1.11)\end{array}$ & $\begin{array}{l}-0.327 \\
(-1.12)\end{array}$ & / & / \\
\hline LLD $\times$ PGR2 & $\begin{array}{l}-0.675 \\
(-1.30)\end{array}$ & $\begin{array}{l}-0.652 \\
(-1.26)\end{array}$ & / & / \\
\hline LLD $\times$ PGR3 & $\begin{array}{l}1.895 * * \\
(8.17)\end{array}$ & $\begin{array}{c}1.904 * * \\
(8.23)\end{array}$ & / & / \\
\hline LLD $\times$ TYD1 & / & / & $\begin{array}{c}0.756^{* *} \\
(5.26)\end{array}$ & $\begin{array}{c}0.750 * * \\
(5.23)\end{array}$ \\
\hline LLD $\times$ TYD2 & / & / & $\begin{array}{l}0.786 \\
(1.63)\end{array}$ & $\begin{array}{l}0.819 \\
(1.70)\end{array}$ \\
\hline LLD $\times$ TYD3 & / & / & $\begin{array}{c}-1.786 * * \\
(-5.74)\end{array}$ & $\begin{array}{c}-1.816 * * \\
(-5.83)\end{array}$ \\
\hline year & control & control & control & control \\
\hline $\mathrm{R}^{2}$ & 0.380 & 0.385 & 0.365 & 0.371 \\
\hline $\mathrm{F}$ & $\begin{array}{l}10.20 * * \\
(0.000)\end{array}$ & $\begin{array}{l}9.602 * * \\
(0.000)\end{array}$ & $\begin{array}{l}9.586 * * \\
(0.000)\end{array}$ & $\begin{array}{l}9.032 * * \\
(0.000)\end{array}$ \\
\hline
\end{tabular}

Notes: $* *$ *denote statistical significance levels at 1\%, 5\%, respectively. The values in parentheses are the adjoint probability values.

Simultaneously, at the different thresholds of $T Y D$, there are three changes in the impact of regional credit on the ratio of industrial structure. When TYD is not higher than 0.047 , that is, in the low-level zone, and the ratio of regional credit has a significant influence on the industrial structure between 0.750 and 0.756 . When TYD was (0.047-0.059], that is, within the medium-level zone, the influence of regional credit on industrial structure was not significant. When TYD is higher than 0.059, that is, within the high-level zone, and the influence of regional credit on industrial structure upgrading significantly turns from positive to negative. The results show that credit supply has a positive adjustment effect on industrial structure in areas with low technology import. In the regions with high technology import, the effect of industrial structure adjustment of credit supply changes from positive to negative. In regions with stronger technology import capabilities, the 
more credit funds are placed on the secondary industry, resulting in a significant decline in the industrial structure. This means that, in developing a modernized economy, the role of technology import in the industrial structure effect of credit is less sustainable. In addition, in models (2) and (3), the interaction terms between indigenous innovation and technology import are not significant and negative. It indicates that the influence of indigenous innovation and technology import on the industrial structure may have a mutual substitution effect, although this effect is not significant.

\section{Conclusions and policy recommendations}

Based on the panel data of 43 prefecture-level cities in Beijing, Tianjin and Hebei from 2009 to 2016, this paper constructs a panel threshold model to conduct an empirical study on the industrial structure effect of regional credit. The results show that there is a double threshold for the structural effect of bank credit in the BeijingTianjin-Hebei. Different technological innovation models will have different impacts on industrial structure upgrading. Under the current economic development level, in the process of measuring the structural effects of Beijing-Tianjin-Hebei credit supply, indigenous innovation plays an increasingly important role in promoting the appropriate transfer of resources from the secondary industry to the tertiary industry. The role is gradually lost or even becomes a negative effect.

The evolution of industrial structure is essentially a process of continuous innovation in technology. In the process of the impact of credit funds on the upgrading of industrial structure, the catalytic role of indigenous innovation is weak and strong, and the technology import is weakened. The realization of the comprehensive role of technological import is closely related to the economic development stage and market environment maturity of a region, and is more related to the appropriate choice of technological innovation model.

In order to effectively play the structural effect of bank credit in the Beijing-TianjinHebei, commercial banks should pay attention to the formulation of credit policies.

1. Guide enterprises to introduce high-quality technology and improve the level of technological innovation in Beijing, Tianjin and Hebei. At this stage, enterprises in most areas of Beijing, Tianjin and Hebei are still labor-intensive industries. In order to give play to the advantages of latecomers, the introduction of advanced technology is an important channel and an inevitable choice for realizing technological progress in the Beijing-Tianjin-Hebei. In the initial journey of technological advancement, which is mainly based on technology import and indigenous innovation, learning and imitation are the main means of technological innovation in the Beijing-Tianjin-Hebei. Historically, Korea and Japan have succeeded in catching up quickly through learning and imitation. First of all, technology introduction must pay attention to the quality of technology. Identifying low-quality technologies and introducing high-quality technologies can reduce the high cost of trial and error and the cost of conversion of results, and quickly promote the practical application of technology. Secondly, pay attention to improving the technology digestion and 
absorption ability of the enterprise in the process of transforming advanced technology, rather than shallow operational skills. Therefore, in the primary development stage of technological innovation, commercial banks should guide enterprises to increase the introduction of technology, especially the introduction of high-quality technology.

2. Supporting indigenous innovation of enterprises in a timely manner and promoting the upgrading of the industrial structure of Beijing-Tianjin-Hebei. The introduction of technology is only the initial stage of the technological innovation process. The technological dependence caused by long-term technology introduction will make the backward areas always in the state of technical dependency, and indigenous innovation is the ultimate means to promote economic development. The 18th National Congress of the Communist Party of China proposed that science and technology innovation must be placed at the core of the overall development of the country and adhere to the road of indigenous innovation with Chinese characteristics. The Beijing-Tianjin-Hebei is also facing key issues and challenges in transforming and owning intellectual property rights and core technologies. The empirical analysis also fully shows that the level of indigenous innovation of Beijing-Tianjin-Hebei has been improved, and the industrial structure upgrading effect brought about by the scale of bank credit and industrial restructuring will become more obvious. Therefore, in the advanced stage of technological innovation, commercial banks should continue to guide and encourage more enterprises to engage in indigenous innovation activities through selective credit supply, improve the overall level of Beijing-Tianjin-Hebei indigenous innovation, and break the control of core technologies in developed regions. We will break through the cycle of technology that cannot be converged, foster high-end industrial sectors with international competitiveness, accelerate the upgrading of industrial structure in the Beijing-Tianjin-Hebei, and realize sustainable economic development in the entire region.

Acknowledgments: This research was funded by the National Social Science Foundation of China (20BJY265), the Humanities and Social Sciences Research Project for Hebei Universities of China (SD172011) and the 2018 Fundamental Scientific Research Funds for the Central Universities of China (ZY20180114).

\section{Author Contributions:}

Qinglu Yuan: literature review, selection of variables, model estimation discussion of results, and conclusions.

Huan Zhou: review of literature, preparation of data and figures, modelling, and testing.

Conflicts of Interest: The authors declare no conflict of interest. 


\section{References}

[1] Angelos, A., Antzoulatos, N. A., \& Al E. (2011). Financial Structure and Industrial Structure. Bulletin of Economic Research,63(2):109-139.

[2] Amore, M. D., Schneider, C., \& Zaldokas, A. (2013). Credit Supply and Corporate Innovation. Journal of Financial Economics,109(3):835-855.

[3] Beck, T., and Levine, R. (2002). Industry Growth and Capital Accumulation: Does Having a Market or Bankbased System Matter? Journal of Financial Economics, (64):147-180.

[4] Binh, K. B., Park, S. Y., and Shin, B. S. (2005). Financial Strucure and Industrial Growth: A Direct Evidence from OECD Countries. Naw Yark: Working Paper.

[5] Ding, Y., Fu, Y., and Cao, Y. (2014). Financial Constraint, Technological Innovation and Stepping Over the Middle Income Trap-An Industrial Structure Upgrading Perspective. Industrial Economics Research, (3):101-110.

[6] Duarte, M., and Restuccia, D. (2009). The Role of the Structural Transformation in Aggregate Productivity. Quarterly Journal of Economics, 125(1):129-173.

[7] Duan, J., and Song, H. (2013). Investment in Science and Technology, Banking Credit and Industrial Structure Upgrading. Review of Industrial Economics,(3):133-145.

[8] Fang, F. Q., and Xing, Wei. (2017). Economic Volatility, Financial Development and the Change of Industrial Enterprises' Technological Progress Mode. Economic Research Journal,52(12):76-90.

[9] Gereffi, G. (1999). International Trade and Industrial Upgrading in the Apparel Commodity Chain. Journal of International Economics,48(1):37-70.

[10] Gong, Y., Gu, G., Liu, C., and Wang, Z. (2013). Chinese industry structure evolution driven by innovation. Studies in Science of Science,31(08):12521259.

[11] Gong, Q., Zhang, Y., and Lin, Y. (2014). Industrial Structure, Risk Feature and Optimal Financial Structure. Economic Research Journal,(4):4-16.

[12] Guo, M., Qian, Z., and Huang, S. (2009). Positive Study on the Effect of Bank Credit to Three Industrial Increases. Industrial Economics Research,(1):26-32.

[13] Hansen, B. E. (1999). Threshold Effects in Non-Dynamic Panels: Estimation, Testing, and Inference. Journal of Econometrics,93(2):345-368.

[14] Huang, W. (2010). Analysis on the Mechanism of Credit Quit for Optimizing Industrial Structure. Finance Forum,15(03):26-32.

[15] Huang, M., and Li, J. (2009). Technology Choice, Upgrade of Industrial Structure and Economic Growth. Economic Research Journal,44(07):143-151.

[16] Lian, L., Chen, C., and Bai, J. (2015). China's Industrial Policy and the Allocation of Credit. Business Management Journal,37(12):1-11.

[17] Lin, Y. F., and Zhang, P. F. (2005). The Advantage of Latter Comers, Technology Imports, and Economic Growth of Developing Countries. China Economic Quarterly, (04):53-74. 
[18] Li, Y., Zhou, H. (2018). Empirical Analysis on the Impact of Regional Credit and Technological Innovation on Economic Growth: Based on the Spatial Panel Perspective. On Economic Problems. 11, 26-35.

[19] Mayer, C., and Vives, X. (1993). Capital Markets and Financial Intermediation. Cambridge University Press, 81-116.

[20] Ngai, L. and Pissarides, C. (2007). Structural Change in a Multisector Model of Growth. American Economic Review,97(1):429-443.

[21] Peneder, M. (2003). Industrial Structure and Aggregate Growth. Structural Change and Economic Dynamics, 14(4):427-448.

[22] Pavitt, K. (1984). Sectoral Patterns of Technical Change Towards an Taxonomy and a Theory. Research Policy,13(6):343-373.

[23] Rajan, R., and Zingales, L. (1998). Financial Dependence and Growth. American Economic Review,88(3):559-586.

[24] Raustiala, K., and Sprigman, C. J. (2012). The Knockoff Economy: How Imitation Sparks Innovation. Social Science Electronic Publishing,43(2):861863.

[25] Schumpeter, J. (1912). The Theory of Economics Development. Cambridge: Harvard University Press.

[26] Saviotti, P. P., and Pyka, A. (2008). Product Variety, Competition and Economic Growth. Journal of Evolutionary Economics, 18(3):323-347.

[27] Sengupta, J. (2014). Theory of Innovation: A New Paradigm of Growth. Switzerland: Springer International Publishing.

[28] Xue, J. (2013). Technology Choice and Transformation and Upgrading of Industrial Structure. Industrial Economics Research, (06):29-37.

[29] Xu, K., and Feng, W. (2010). The Industry Upgrading with Endogenous Home Market Size: The Third Path of Technological Innovation. China Industrial Economics, (11):58-67.

[30] Zhao, L., and Li, Z. (2010). Credit Support, Government Spending and the Relevant Mechanism of Industrial Upgra-ding. Journal of Guangdong University of Finance,(5):20-30.

[31] Zhou, H., Qu, S., Wu, Z. et al. (2020). A study of environmental regulation, technological innovation, and energy consumption in China based on spatial econometric models and panel threshold models. Environ Sci Pollut Res. https://doi.org/10.1007/s11356-020-09793-y 